\title{
Akuntansi Manajemen Limbah Industri Perhotelan (Studi kasus: Sebuah Hotel Bintang Empat di Makassar)
}

\author{
Surahmah Kurnia \\ Jurusan Akuntansi Politekinik Negeri Ujung Pandang \\ Syamsinar \\ Jurusan Akuntansi Politekinik Negeri Ujung Pandang \\ syamsinar_muhtar@yahoo.co.id \\ Afdaliah \\ Jurusan Akuntansi Politekinik Negeri Ujung Pandang \\ (Diterima: 01-Januari-2019; dipublikasikan: 31-Januari-2020)
}

\begin{abstract}
The purpose of this research is to produce the accounting information for management decision making about the estimation of revenue and cost of waste cultivation in hotel. The research methodology used descriptive quantitative using waste material exchange and recycle as the alternatives waste cultivation. The empirical result shows that the estimation of financial performance (profit) which sourced from solid and liquid waste cultivation based on the parameter used will be consideration and recommendation. .
\end{abstract}

Keywords: Accounting, Waste, Hotel, Waste cultivation, Financial performance

\begin{abstract}
Abstrak
Tujuan penelitian ini adalah menghasilkan suatu proses penyusunan informasi akuntansi untuk pengambilan keputusan manajemen yang spesifik mengenai estimasi pendapatan dan beban pengelolaan limbah hotel. Metode penelitian yang digunakan adalah metode deskriptif kuantitatif sesuai dengan alternatif-alternatif pengelolaan limbah. Dua alternatif pengelolaan limbah yang digunakan adalah waste material exchange atau tukar-menukar untuk limbah padat dan recycle atau daur ulang limbah padat organik dan limbah cair. Hasil penelitian ini memperlihatkan estimasi kinerja keuangan (profit) yang bersumber dari pengelolaan limbah padat dan cair berdasarkan pilihan alternatif yang akan menjadi bahan perbandingan dan rekomendasi
\end{abstract}

Kata Kunci: Akuntansi, Limbah, Hotel, Pengelolaan Limbah, Kinerja keuangan

\section{PENDAHULUAN}

Kondisi lingkungan saat ini masih berada dalam keadaan yang memperihatinkan. Data Badan Lingkungan Hidup Daerah Kota Makassar (2015) Sumber?) menyebutkan bahwa kerusakan lingkungan selama kurun waktu 10 tahun terakhir meningkat, akibatnya terjadi kerusakan lingkungan. Kondisi lingkungan yang seperti ini akan memacu terjadinya pencemaran lingkungan yang cepat. Pencemaran yang terjadi telah mempangaruhi semua aspek lingkungan baik pencemaran air, pencemaran udara, maupun pencemaran tanah. Dalam Undang-undang No. 32 Tahun 2009 dijelaskan bahwa "Polusi atau pencemaran lingkungan adalah masuknya atau dimasukkannya makhluk hidup, zat energi, dan atau komponen lain ke dalam lingkungan, atau berubahnya tatanan lingkungan oleh kegiatan manusia atau oleh proses alam sehingga kualitas lingkungan turun sampai ke tingkat tertentu yang menyebabkan lingkungan menjadi kurang 
atau tidak dapat berfungsi lagi sesuai dengan peruntukannya."

Limbah memiliki hubungan yang erat dengan pencemaran lingkungan. Limbah menjadi penyebab pencemaran lingkungan karena dengan kuantitas tertentu, kehadiran limbah dapat berdampak negatif terhadap lingkungan terutama bagi kesehatan masyarakat. Data Dinas Kementerian Lingkungan Hidup Kota Makassar (2015) menyebutkan rata-rata produksi sampah di Kota Makassar mencapai 871 ton per hari dengan mengacu dari jumlah penduduk sekitar 1,3 juta orang. Salah satu penghasil limbah yang besar disebabkan oleh adanya aktivitas industri yang berskala besar. Salah satu industri yang menyebabkan kerusakan lingkungan adalah industri perhotelan. Limbah industri perhotelan dipengaruhi oleh banyaknya jumlah tamu. Limbah yang paling banyak dihasilkan oleh industri perhotelan adalah limbah padat dan limbah cair. Limbah padat yang dihasilkan oleh industri perhotelan berupa limbah padat anorganik dan limbah padat organik serta limbah cair. Limbah cair adalah limbah air buangan yang berasal dari aktivitas yang terjadi di kamar, dapur, laundry, dan berbagai aktivitas yang menggunakan air.

Karena memiliki dampak yang sangat buruk, maka pemerintah mewajibkan setiap pihak yang melakukan usaha atau kegiatan untuk melakukan pengelolaan terhadap limbah-limbah yang dihasilkan sesuai dengan Peraturan Pemerintah No.32 Tahun 2009 Tentang Perlindungan dan Pengelolaan Lingkungan Hidup.

Pengembangan pola konsumsi dan produksi berkelanjutan telah masuk dalam Rencana Pembangunan Jangka Menengah Nasional (RPJMN) Tahun 2015 - 2019. Kebijakan tersebut memungkinkan sinergi antar program pemerintah secara lebih terpadu seperti konservasi, pemanfaatan sumber daya hutan dan jasa ekosistem, pengendalian pencemaran, produksi bersih, ekolabel (produk ramah lingkungan), Adiwiyata (sekolah berwawasan lingkungan), pemberdayaan masyarakat, pengelolaan sampah dan 3R ('Reduce-ReuseRecycle").
Menurut Suriana (2010), pengelolaan limbah dapat dilakukan dengan cara penggunaan kembali (reuse), daur ulang (recycle) dan tukar-menukar limbah (waste material exchange). Limbah padat anorganik yang dihasilkan hotel tergolong dalam limbah yang memiliki nilai ekonomis karena limbah tersebut masih bisa didaur ulang, seperti limbah plastik, botol minuman, kaleng minuman, sandal, dan kertas. Cara yang paling tepat untuk menangani limbah tersebut dengan dijual kembali kepada para distributor yang memasok barang-barang tersebut. Adapun limbah padat organik yang dihasilkan pihak hotel dapat dijual kepada pengusaha yang memiliki usaha dalam pengelolaan organik dan dapat didaur ulang oleh pihak hotel sendiri.

Limbah cair perhotelan biasanya mengandung unsur padatan, surfactant seperti sabun dan deterjen, karbohidrat, protein, minyak, lemak, alkalinity, chloride, nitrogen, phosphor, sulfur, protista, virus, dan lain-lain. Jika kandungan yang ada pada limbah cair melebihi baku mutu lingkungan air dan limbah cair perhotelan maka akan menyebabkan kerusakan lingkungan sehingga pihak hotel harus melakukan pengelolaan terhadap limbah cair tersebut agar sesuai dengan baku mutu air dan limbah cair perhotelan yang telah ditentukan pada Keputusan Menteri Lingkungan Hidup No: KEP-52/MENLH/10/1995.

Jika pihak hotel melakukan pengelolaan terhadap limbahnya, maka akan memberikan manfaat baik bagi pihak hotel maupun masyarakat. Manfaat yang dapat diterima dari pengelolaan limbah tersebut adalah meminimalkan kemungkinan terjadinya kerusakan lingkungan yang membahayakan kesehatan masyarakat sehingga kondisi lingkungan yang ada disekitar masyarakat menjadi lebih bersih. Pihak hotel bertanggung jawab terhadap gerakan untuk mencegah terjadinya pencemaran lingkungan sehingga bisa menjadi bentuk corporate social responsibility pihak hotel. Hasil dari pengelolaan limbah tersebut juga bisa memberikan manfaat ekonomis bagi pihak hotel serta bisa menjadi produk yang berguna bagi masyarakat sekitar.

Aktivitas pengelolaan limbah industri 
pada dasarnya berdampak pada kenaikan pendapatan dan kenaikan beban pengelolaan. Berdasarkan beberapa alternatif pengelolaan yang direkomendasikan oleh para ahli, dapat dijadikan pertimbangan oleh manajemen untuk melaksanakan kewajiban sosialnya sekaligus meningkatkan ekonomi perusahaan atau kinerja keuangan. Untuk itu, dibutuhkan suatu proses akuntansi untuk menyajikan laporan estimasi kinerja keuangan sebagai hasil dari aktivitas tersebut. Penelitian ini mengidentifikasi potensi pendapatan dan beban pengelolaan limbah hotel berdasarkan alternatif-alternatif pengelolaan limbah.

Sistem informasi akuntansi manajemen menyediakan informasi yang dibutuhkan untuk memenuhi tujuan tertentu manajemen (Hansen and Mowen, 2007). Manajemen perusahaan bertanggungjawab untuk memberikan nilai baik kepada stakeholders maupun masyarakat. Oleh karena itu, dibutuhkan suatu keseimbangan antara tujuan ekonomis dengan tujuan sosial dan lingkungan. Informasi terkait dengan keputusan manajemen dalam hal ini sangat penting untuk mencapai atau mendekati kesimbangan tersebut. Salah satu informasi yang cukup penting adalah informasi keuangan khususnya pendapatan dan beban yang terkait dengan aktivitas pengelolaan limbah.

Pendapatan adalah arus masuk bruto dari manfaat ekonomi yang timbul dari aktivitasaktivitas normal perusahaan selama suatu periode bila arus masuk tersebut mengakibatkan kenaikan ekuitas yang tidak berasal dari kontribusi penanaman modal PSAK No.23 paragraf 2 (2012:23). Kriteria pengakuan pendapatan yang harus dipenuhi yaitu terealisasinya atau cukup pastinya terealisasi dan terbentuk/terhak (SFAC No.5: 83 dalam Suwardjono 2014). Adapun beban (expenses) adalah biaya yang dikorbankan atau dikonsumsi dalam rangka memperoleh pendapatan (revenues) dalam suatu periode akuntansi tertentu (Supriyono, 2011). Syarat pengakuan beban adalah bilamana manfaat ekonomik yang dikuasai suatu entitas telah dimanfaatkan atau dikonsumsi dan/atau lenyapnya atau berkurangnya manfaat masa depan suatu aset yang telah diakui sebelumnya dan diperkirakan telah berkurang manfaat ekonominya atau tidak lagi mempunyai manfaat ekonomik.

Limbah merupakan buangan yang dihasilkan dari suatu proses produksi dapat berupa sampah, black water, dan ada air buangan dari berbagai aktivitas domestik lainnya (Daryanto, 2013). Bila ditinjau secara kimiawi, limbah ini terdiri dari bahan kimia organik dan anorganik (Astari, 2015). Berdasarkan nilai ekonomisnya, terdiri atas limbah yang mempunyai nilai ekonomis dan limbah non-ekonomis. Limbah yang mempunyai nilai ekonomis yaitu limbah dengan proses lanjut akan memberikan nilai tambah. Limbah non-ekonomis adalah limbah yang diolah dalam proses bentuk apapun tidak akan memberi nilai tambah, kecuali mempermudah sistem pembuangan. Limbah jenis ini sering menjadi persoalan pencemaran dan merusak lingkungan. Menurut Suriana (2010), pengelolaan limbah membutuhkan biaya besar karena didalam proses pengelolaannya diperlukan peralatan dan teknologi yang canggih. Di Indonesia setiap industri yang menghasilkan limbah tidak perlu membangun unit pengelolaan limbah karena tidak ekonomis dan efisien. Akan tetapi limbah dikumpulkan dan disimpan dengan baik sehingga aman bagi lingkungan. Setelah jumlahnya cukup, dikirim ke perusahaan yang khusus mengelola limbah. Limbah dapat dimanfaatkan dengan cara, yaitu a) Penggunaan kembali (reuse) yaitu pemanfaatan limbah dengan dengan jalan menggunakannya kembali untuk kepentingan yang sama, tanpa mengalami pengolahan, b) Daur ulang (recycle) yaitu pemanfaatan limbah melalui pengolahan fisik atau kimiawi, contohnya kertas bekas diolah kembali menjadi kertas baru atau benda lain, dan c) Tukar-menukar limbah (waste material exchange) yaitu upaya pemanfaatan limbah dengan jalan tukar-menukar atau membeli dan menjual limbah. Hal ini saling menguntungkan karena yang menghasilkan limbah dapat mengurangi biaya pengelolaan, sedangkan pengguna limbah mendapatkan bahan mentahnya. 
Menurut Daryanto (2013), pengelolaan limbah padat menurut sifatnya dibagi menjadi 2 (dua) cara, yaitu: a) limbah padat tanpa pengolahan untuk limbah padat yang tidak mengandung unsur kimia yang beracun dan berbahaya biasa langsung dibuang ketempat tertentu sebagai TPA. b) limbah padat dengan pengolahan, yaitu limbah padat yang mengandung unsur kimia beracun dan berbahaya harus diolah sebelum dibuang ke tempat tertentu. Adapun pengelolaan limbah cair, ada beberapa faktor yang mempengaruhi kualitas limbah yaitu volume limbah, kandungan bahan pencemar, dan frekuensi pembuangan limbah. Untuk mengatasi limbah ini diperlukan pengolahan dan penanganan limbah. Pada dasarnya limbah ini dapat dibedakan menjadi a) pengolahan menurut tingkat perlakuan, dan b) pengolahan menurut karakteristik limbah. Baku mutu limbah cair hotel adalah batas maksimum limbah cair yang diperbolehkan dibuang ke lingkungan. Baku mutu limbah cair hotel menurut Keputusan Menteri Lingkungan Hidup Nomor: KEP-52/MENLH/10/1995 tentang "Baku Mutu Limbah Cair Bagi Kegiatan Hotel" seperti pada tabel berikut:

Tabel 1 Baku Mutu Limbah Cair Perhotelan

\begin{tabular}{cc}
\hline PARAMMETER & $\begin{array}{c}\text { KADAR MAKSIMUM } \\
(\mathbf{m g} / \mathbf{L})\end{array}$ \\
\hline BOD $_{5}$ & 30 \\
\hline $\mathrm{COD}$ & 50 \\
\hline $\mathrm{TSS}$ & 500 \\
\hline $\mathrm{pH}$ & $6,0-9,0$ \\
\hline
\end{tabular}

Sumber: Keputusan Menteri Lingkungan Hidup nomor KEP-52/MENLH/10/95

\section{METODE PENELITIAN}

Metode analisis yang digunakan adalah metode deskriptif kuantitatif yaitu mendeskripsikan hasil temuan yang berasal dari data yang terkumpul kemudian dianalisis secara kuantitatif dengan tahapan-tahapan berikut.

Pertama, mengidentifikasi jenis limbah yang dihasilkan hotel, potensi beban dari pengelolaan limbah, dan harga jual limbah padat hotel. Tahap kedua adalah memilih alternatif pengelolaan limbah. Tahap selanjutnya, menyusun estimasi pendapatan dan beban pengelolaan. Tahap kelima atau tahap terakhir, menyusun estimasi laporan laba rugi dari pengelolaan limbah hotel.

\section{HASIL DAN PEMBAHASAN}

Limbah padat hotel terdiri dari limbah padat anorganik (sebagaimana terlihat pada tabel) dan limbah padat organik yang berasal dari kamar-kamar hotel, departemen karaoke, departemen botol music, departemen gallery, departemen Jacuzzi, dan kitchen. Limbah cair hotel berasal dari kamar-kamar hotel, kitchen, dan laundry.

Tabel 2 Jumlah rata-rata perbulan jenis limbah padat anorganik

\begin{tabular}{lrl}
\hline \multicolumn{1}{c}{ Item } & $\begin{array}{c}\text { Rata- } \\
\text { rata / } \\
\text { bln }\end{array}$ & Sat \\
\hline Aki Bekas & 13 & $\mathrm{Kg}$ \\
Baterai & 5 & $\mathrm{Kg}$ \\
Botol Bahan Makanan Kemasan & 180 & $\mathrm{Btl}$ \\
Botol Bir Bintang PL & 600 & $\mathrm{Btl}$ \\
Botol Heineken Pint 330ml & 840 & $\mathrm{Btl}$ \\
Botol Minuman Beralkohol & 175 & $\mathrm{Btl}$ \\
Botol The & 600 & $\mathrm{Btl}$ \\
Comb & 4.560 & $\mathrm{Pcs}$ \\
Gelas Plastik & 6.840 & $\mathrm{Pcs}$ \\
Jerigen & 50 & $\mathrm{Pcs}$ \\
Hand Soap HK/Sabun Logo & 2.280 & $\mathrm{Pcs}$ \\
Kaleng Bahan Makanan Kemasan & 28 & $\mathrm{Kg}$ \\
Kaleng Minuman & 56 & $\mathrm{Kg}$ \\
Karton & 5 & $\mathrm{Kg}$ \\
Kertas & 35 & $\mathrm{Kg}$ \\
Oli Bekas & 7,5 & $\mathrm{Ltr}$ \\
Plastik Botol Air Mineral & 170 & $\mathrm{Kg}$ \\
Razor/Shaving Kit & 760 & $\mathrm{Pcs}$ \\
Sendok Plastik & 4.560 & $\mathrm{Pcs}$ \\
Shampoo HK & 2.280 & $\mathrm{Pcs}$ \\
Shower Gel & 2.280 & $\mathrm{Pcs}$ \\
Slipper Logo & 4.560 & $\mathrm{Pcs}$ \\
Tooth Brush & 4.560 & $\mathrm{Pcs}$ \\
\hline & & \\
\hline
\end{tabular}

Sumber: departemen housekeeping, 2015 (data diolah) 
Untuk limbah padat anorganik berupa baterai dan oli bekas, perusahaan membayar iuran setiap bulannya kepada perusahaan yang khusus mengelola dan mengumpulkan limbah bahan berbahaya dan beracun (limbah b3). Pihak hotel dapat mengeluarkan beban pengepakan dan penyimpanan terhadap limbah padat anorganik yang dihasilkannya. Potensi beban-beban pengelolaan tersebut dapat dilihat pada tabel berikut:

Tabel 3 Potensi Beban-beban Pengelolaan Limbah Padat Anorganik per Bulan

\begin{tabular}{lc}
\hline Keterangan & $\begin{array}{c}\text { Jumlah } \\
(\mathbf{R p})\end{array}$ \\
\hline $\begin{array}{l}\text { Beban pengepakan limbah padat } \\
\text { anorganik }\end{array}$ & 30.000 \\
\hline Beban pengelolaan limbah baterai & 5.000 \\
\hline Beban pengelolaan limbah oli bekas & 15.000 \\
\hline & \\
Beban penyimpanan limbah & 50.000 \\
\hline
\end{tabular}

Sumber: Dep.engineering,2015(data diolah)

Tabel 4 Daftar Haga Jual Limbah Padat Anorganik

\begin{tabular}{|c|c|c|}
\hline Keterangan & $\begin{array}{c}\text { Harga } \\
\text { (Rp) }\end{array}$ & Sat \\
\hline Aki Bekas & 10.000 & $\mathrm{Kg}$ \\
\hline Botol Bahan Makanan Kemasan & 1.250 & Pcs \\
\hline Botol Bir Bintang Pl & 1.750 & Pcs \\
\hline Botol Heineken Pint 330ml & 1.250 & Pcs \\
\hline Botol Minuman Keras & 15.000 & Pcs \\
\hline Botol The & 550 & Pcs \\
\hline Comb & 200 & Pcs \\
\hline Gelas Plastik & 250 & Pcs \\
\hline Jerigen & 10.000 & Pcs \\
\hline Hand Soap Hk/Sabun Logo & 420 & Pcs \\
\hline Kaleng Bahan Makanan Kemasan & 10.000 & $\mathrm{Kg}$ \\
\hline Kaleng Minuman & 10.000 & $\mathrm{Kg}$ \\
\hline Karton & 1.200 & $\mathrm{Kg}$ \\
\hline Kertas & 1.700 & $\mathrm{Kg}$ \\
\hline Plastik Botol Air Mineral & 4.000 & $\mathrm{Kg}$ \\
\hline Razor/Shaving Kit & 220 & Pcs \\
\hline Sendok Plastik & 50 & Pcs \\
\hline Shampoo Hk & 400 & Pcs \\
\hline Shower Gel & 450 & Pcs \\
\hline Slipper Logo & 1,000 & Pcs \\
\hline Tooth Brush & 420 & Pcs \\
\hline
\end{tabular}

Sumber: Depart. purchasingdan pengusaha pengumpul dan pengelola limbah, 2015 (data diolah).
Pemanfaatan limbah yang dipilih untuk pengelolaan terhadap limbah padat anorganik yaitu Waste material exchange atau tukarmenukar limbah. Pemanfaatan ini dipilih karena limbah yang dihasilkan hotel masih memiliki nilai ekonomis dan sangat memungkinkan untuk dijual kembali kepada pihak distributor maupun kepada perusahaan yang bergerak di bidang pengelolaan limbah. Dengan cara ini, pihak hotel mendapat manfaat berupa penambahan pendapatan tanpa melakukan kegiatan pengelolaan yang lama serta biaya yang mahal. Cara pemanfaatan reuse atau penggunaan kembali tidak tepat dilakukan terhadap limbah padat anorganik hotel karena limbah padat hotel tersebut berupa kemasan produk serta benda tertentu. Kemasan produk dan benda tersebut merupakan produk yang tidak dapat diproduksi oleh pihak hotel sendiri. Cara recycle atau mendaur ulang tidak tepat diterapkan pada limbah padat anorganik hotel, karena untuk mendaur ulang semua limbah padat anorganik tersebut akan membutuhkan waktu yang banyak, tempat pengelolaan khusus, tenaga kerja khusus, dan mesin pengelolaan khusus sehingga menimbulkan biaya yang sangat besar. Hasil daur ulang tersebut juga harus dijual atau dimanfaatkan lagi. Para pembeli limbah padat anorganik tersebut merupakan pihak yang mengelola usaha pengumpul dan pengelolaan limbah padat dan pihak distributor hotel. Untuk limbah padat berupa bahan berbahaya dan beracun (b3) dikumpulkan oleh perusahaan pengelola limbah yang khusus mengelola limbah yang mengandung bahan berbahaya dan beracun. Untuk limbah padat anorganik yang berupa botol kemasan dan produk yang memiliki logo hotel sulit untuk dijual kepada pihak distributor. Untuk kasus ini, alternatif sterilisasi botol kemasan bekas dapat dilakukan untuk kemudian digunakan kembali. Atau dapat juga memilih alternatif pencegahan yaitu dengan menggunakan logo yang dapat terlepas dari wadah atau kemasan.

\section{Limbah Padat Organik Hotel}

Limbah padat organik yang dihasilkan hotel ada 2 (dua) jenis, yaitu limbah sisa 
makanan dan minyak jelantah. Untuk limbah sisa makanan yang dihasilkan hotel, bagian kitchen memiliki saluran pembuangan yang langsung menghubungkan antara pembuangan yang ada di kitchen dengan tempat penampungan limbah makanan. Tempat penampungan limbah makanan tersebut dapat menampung hingga $5 \mathrm{~m}^{2}$ limbah makan. Limbah yang berupa minyak jelantah dikumpulkan di dalam jerigen kemudian disimpan di kitchen. Kuantitas dari limbah padat organik yang dihasilkan oleh hotel dapat dilihat pada tabel berikut.

Tabel 5 Jumlah Rata-rata Perbulan Jenis Limbah Padat Organik

\begin{tabular}{lll}
\hline \multirow{2}{*}{ Keterangan } & \multicolumn{2}{c}{ Jumlah Limbah Makanan } \\
\cline { 2 - 3 } & \multicolumn{1}{c}{ Perhari } & Perbulan \\
\hline Limbah Makanan & $50 \mathrm{~kg}$ & $1.500 \mathrm{~kg}$ \\
\hline Minyak Jelantah & $7,5 \mathrm{Liter}$ & $225 \mathrm{Liter}$ \\
\hline
\end{tabular}

Sumber: Dep.engineering,2015(data diolah)

Adapun potensi yang menjadi beban-beban dalam pengelolaan limbah adalah tergambar dalam tabel berikut.

Tabel 6 Beban-beban Pengelolaan Limbah Padat Organik Hotel Perbulan

\begin{tabular}{lc}
\hline \multicolumn{1}{c}{ Keterangan } & $\begin{array}{c}\text { Jumlah } \\
(\mathbf{R p})\end{array}$ \\
\hline $\begin{array}{l}\text { Beban Gaji Penanganan Limbah Or- } \\
\text { ganik }\end{array}$ & 1.300 .000 \\
\hline $\begin{array}{l}\text { Beban Penampungan Limbah Organik } \\
\text { Sisa Makanan }\end{array}$ & 50.000 \\
\hline
\end{tabular}

Sumber: Departemen engineering, 2015 (data diolah)

Sementara daftar harga jual lombah padat organik hotel adalah sebagai berikut :

Tabel 7 Daftar Harga Jual Limbah Padat Organic

\begin{tabular}{lccc}
\hline \multicolumn{1}{c}{ Keterangan } & Harga & Sat. \\
\hline Limbah Makan & $\mathrm{Rp}$ & 1.500 & $\mathrm{Kg}$ \\
\hline Minyak Jelantah & $\mathrm{Rp}$ & 4.250 & $\mathrm{Ltr}$ \\
\hline
\end{tabular}

Sumber: Perusahaan pengelola minyak jelantah dan pengelola limbah makan, 2015 (data diolah)

\section{Alternatif Pengelolaan Limbah Padat Or- ganik Hotel}

Pengelolaan terhadap limbah padat organik pada penelitian ini memilih alternatif pemanfaatan dengan menggunakan cara waste material exchange atau tukar menukar limbah dan recycle atau mendaur ulang limbah. Kedua alternatif ini dipilih karena cara pemanfaatan tersebut mampu dilakukan oleh pihak hotel dan kondisi di hotel juga memungkinkan untuk melakukan kegiatan ini. Pemanfaatan dengan cara reuse atau penggunaan kembali tidak tepat dilakukan pihak hotel untuk limbah padat organiknya, karena limbah padat organik tersebut sudah tidak dapat dikonsumsi oleh konsumen hotel. Kualitas dari limbah padat organik tersebut juga sudah tidak memenuhi standar dari produk-produk yang disajikan oleh pihak hotel. Berikut pemaparan untuk setiap alternatif yang dipilih untuk pengelolaan limbah padat organik:

1. Alternatif waste material exchange atau tukar menukar limbah

Pada alternatif ini, limbah padat organik yang berupa sisa makanan dan minyak jelantah dijual kepada pihak-pihak pengelolah limbah makanan dan minyak jelantah. Limbah makanan ditawarkan dengan harga Rp 1.500 per kilogramnya dan minyak jelantah ditawarkan $\mathrm{Rp} 4.250$ perliternya. Untuk saat ini, usaha yang bergerak di bidang pengelolaan limbah sisa makanan belum ada di kota Makassar. Potensi dari bisnis pengelolaan limbah makanan tersebut sangat tinggi karena mampu menghasilkan keuntungan yang banyak serta merupakan usaha penyedia jasa yang dibutuhkan oleh banyak pihak yang tidak bisa mengelola limbah makanannya sendiri. Berdasarkan hal tersebut, maka tidak menutup kemungkinan dalam waktu dekat akan banyak usaha yang bergerak di bidang pengelolaan limbah makanan di kota Makassar. Untuk usaha yang bergerak di bidang pengelolaan limbah minyak jelantah sudah ada yang beroperasi di kota Makassar. Pihak hotel sudah bekerja sama dengan pihak pengelolah limbah minyak jelantah tersebut untuk membeli minyak jelantah yang dihasilkan hotel. 
2. Alternatif recycle atau mendaur ulang

Pihak hotel dapat mendaur ulang limbah padat organik tersebut menjadi produk tertentu, namun limbah padat yang memungkinkan untuk didaur ulang hanya limbah padat organik yang berupa limbah sisa makanan. Limbah organik yang berupa minyak jelantah tidak memungkinkan untuk didaur ulang oleh pihak hotel karena membutuhkan mesin tertentu dan penanganan yang khusus. Jika pihak hotel ingin mendaur ulang sendiri minyak jelantah tersebut akan membutuhkan biaya yang besar, hasil dari pengelolaan minyak jelantah juga sudah tidak bisa digunakan oleh pihak hotel, karena untuk minyak goreng yang digunakan pihak hotel memiliki standar kualitas tertentu. Jika hasil pengelolaan minyak jelantah ingin dijual maka pihak hotel harus mencari pembeli untuk hasil olahannya sehingga memerlukan penanganan khusus sehingga akan mempersulit pihak hotel. Untuk limbah padat organik yang berupa limbah makanan, pihak hotel bisa mendaur ulang dengan beberapa cara penanganan. Menurut Subardo (2013) metode penanganan limbah organik dapat dilakukan dengan 3 (tiga) cara yaitu dengan metode composting, gas bio, dan makanan ternak.

Pada penelitian ini, metode yang digunakan adalah metode composting. Metode composting mudah dilakukan oleh pihak hotel dan tidak membutuhkan biaya yang besar untuk pengelolaannya. Hasil dari pengelolaan limbah tersebut juga bisa dijadikan pupuk bagi tumbuhan yang ada disekitar hotel, bahkan bisa menjadi salah satu bentuk corporate social responsibility di bidang lingkungan bagi hotel.

Menggunakan metode gas bio untuk penanganan terhadap limbah padat sisa makanan kurang tepat. Bahan-bahan yang digunakan untuk membuat gas bio yaitu limbah yang berupah kotoran hawan dan kotoran manusia, karena untuk membuat gas bio diperlukan kandungan metana, karbondioksida, nitrogen, karbonmonoksida, oksigen, hydrogen sulfide.

Mendaur ulang limbah makanan menjadi makanan ternak kurang tepat dilakukan karena proses pengelolaannya memerlukan penanganan khusus. Membuat makanan ternak membutuhkan proses yang panjang dimulai pemisahan sampah organik dan anorganik, dilanjutkan dengan pencacahan, fermentasi, pengeringan, penepungan, pencampuran, dan pembuatan makanan ternak. Makanan ternak dari limbah sisa makanan juga harus diolah dengan penangan yang benar, karena hasil dari olahan tersebut dapat mengandung bahan yang dapat membahayakan kesehatan ternak disamping membutuhkan biaya yang besar dalam pengelolaannya.

Mendaur ulang limbah makanan menggunakan metode composting menghasilkan pupuk kompos yang dapat menyuburkan tanah sehingga dapat digunakan pihak hotel untuk menyuburkan tumbuhan yang ada disekitar lingkungannya. Sistem pengomposan memilki beberapa keuntungan, diantaranya yaitu pupuk kompos merupakan jenis pupuk yang ekologis dan tidak merusak lingkungan, bahan yang dipakai tersedia, dan dapat dibuat sendiri.

\section{Limbah Cair Hotel}

Limbah cair hotel berasal dari 3 sumber, yaitu limbah cair kamar, limbah cair kitchen, dan limbah cair laundry. Tempat penampungan limbah cair tersebut juga dibedakan berdasarkan sumber limbah cair. Tempat penampungan limbah cair kamar mampu menampung hingga $25 \mathrm{~m}^{2}$ limbah cair. Tempat penampungan limbah cair laundry mampu menampung hingga $20 \mathrm{~m}^{2}$ limbah cair. Tempat penampungan limbah cair kitchen mampu menampu hingga $30 \mathrm{~m}^{2}$ limbah cair. Jumlah limbah cair yang dihasilkan hotel sebagai berikut:

Tabel 8 Jumlah Rata-rata Perbulan Limbah Cair Hotel

\begin{tabular}{llc}
\hline \multirow{2}{*}{ Keterangan } & \multicolumn{2}{c}{ Volume Limbah Cair } \\
\cline { 2 - 3 } & Perhari & Perbulan \\
\hline Limbah Cair Kamar & $0,5 \mathrm{~m}^{2}$ & $15 \mathrm{~m}^{2}$ \\
\hline Limbah Cair Kitchen & $0,7 \mathrm{~m}^{2}$ & $21 \mathrm{~m}^{2}$ \\
\hline Limbah Cair Laundry & $0,3 \mathrm{~m}^{2}$ & $9 \mathrm{~m}^{2}$ \\
\hline
\end{tabular}

Sumber: Departemen engineering hotel, 2015 (data diolah) 
Pengelolaan limbah cair hotel menggunakan sistem Biotek. Proses pengelolaan sistem ini melalui 6 (enam) tahapan. Proses pengelolaan tersebut menimbulkan banyak biaya dalam proses pengelolaannya.

\section{Tabel 9 Beban Pengelolaan Limbah Cair Perbulan}

\begin{tabular}{lr}
\hline \multicolumn{1}{c}{ Keterangan } & \multicolumn{1}{c}{ Jumlah (Rp) } \\
\hline Beban Uji Laboraturium & 150.000 \\
\hline Beban Chemical & 35.000 \\
\hline Beban Teskit & 100.000 \\
\hline Beban Kertas Lakmus & 50.000 \\
\hline $\begin{array}{l}\text { Beban Penyusutan Tabung } \\
\text { Pengelolaan Limbah Cair }\end{array}$ & 1.527 .778 \\
\hline Beban Perizinan Baku Mutu & \\
Limbah Cair & 27.778 \\
\hline
\end{tabular}

Menurut Daryanto (2013:238-239) beberapa faktor yang mempengaruhi kualitas limbah cair adalah volume limbah, kandungan bahan pencemar, dan frekuensi pembuangan limbah. Untuk mengatasi limbah ini diperlukan pengolahan dan penanganan limbah. Adapun metode yang dapat diterapkan oleh pihak hotel yaitu metode biotek, metode ini dimodifikasi sesuai dengan kebutuhan pengelolaan limbah hotel dan untuk menghemat biaya yang dikeluarkan. Metode biotek cocok digunakan oleh hotel karena tidak membutuhkan tempat yang banyak, mudah dalam proses pengelolaannya, dan biayanya relatif murah.

\section{Estimasi Pendapatan dan Beban Pengelola- an Limbah Hotel}

Sumber: Departemen engineering, 2015 (data diolah)

Tabel 10 Estimasi pendapatan dari hasil penjualan limbah padat anorganik berdasarkan metode tukar menukar limbah perbulan

\begin{tabular}{|c|c|c|c|c|}
\hline Ket. & Jml & Sat. & $\begin{array}{c}\text { Harga Per Satuan } \\
\text { (Rp) }\end{array}$ & $\begin{array}{c}\text { Estimasi Hasil Penjualan } \\
\text { Perbulan (Rp) }\end{array}$ \\
\hline Aki Bekas & 13 & $\mathrm{Kg}$ & 10.000 & 130.000 \\
\hline Botol Makanan Kemasan & 180 & Btl & 1.250 & 225.000 \\
\hline Botol Bir Bintang PL & 600 & Btl & 1.750 & 1.050 .000 \\
\hline Botol Heineken Pint 330ml & 840 & Btl & 1.250 & 1.050 .000 \\
\hline Botol Minuman Beralkohol & 175 & Btl & 15.000 & 2.625 .000 \\
\hline Botol Teh & 600 & Btl & 550 & 330.000 \\
\hline Comb & 4.560 & Pcs & 200 & 912.000 \\
\hline Gelas Plastik & 6.840 & Pcs & 250 & 1.710 .000 \\
\hline Jerigen & 50 & Pcs & 10.000 & 500.000 \\
\hline Hand Soap HK/Sabun Logo & 2.280 & Pcs & 420 & 957.600 \\
\hline Kaleng Makanan Kemasan & 28 & $\mathrm{Kg}$ & 10.000 & 280.000 \\
\hline Kaleng Minuman & 56 & $\mathrm{Kg}$ & 10.000 & 560.000 \\
\hline Karton & 5 & $\mathrm{Kg}$ & 1.200 & 6.000 \\
\hline Kertas & 35 & $\mathrm{Kg}$ & 1.700 & 59.500 \\
\hline Plastik Botol Air Mineral & 170 & $\mathrm{Kg}$ & 4.000 & 680.000 \\
\hline Razor/Shaving Kit & 760 & Pcs & 220 & 167.200 \\
\hline Sendok Plastik & 4.560 & Pcs & 50 & 228.000 \\
\hline Shampoo HK & 2.280 & Pcs & 400 & 912.000 \\
\hline Shower Gel & 2.280 & Pcs & 450 & 1.026 .000 \\
\hline Slipper Logo & 4.560 & Pcs & 1.000 & 4.560 .000 \\
\hline \multirow[t]{2}{*}{ Tooth Brush } & 4.560 & Pcs & 420 & 1.915 .200 \\
\hline & & & Total & 19.883 .500 \\
\hline
\end{tabular}

Sumber: Data diolah (2015) 
Tabel 11 Estimasi Pendapatan dari Hasil Penjualan Limbah Padat Organik Berdasarkan Metode Tukar Menukar Limbah Perbulan

\begin{tabular}{lccc}
\hline Ket. & $\begin{array}{c}\text { Jumlah } \\
\text { Limbah } \\
\text { Perbln }\end{array}$ & $\begin{array}{c}\text { Harga } \\
\text { Jual } \\
(\mathrm{Rp})\end{array}$ & $\begin{array}{c}\text { Estimasi Ha- } \\
\text { sil Penjualan } \\
\text { Perbln (Rp) }\end{array}$ \\
\hline $\begin{array}{l}\text { Limbah } \\
\text { Makanan }\end{array}$ & $1.500 \mathrm{Kg}$ & 1.500 & 2.250 .000 \\
\hline $\begin{array}{l}\text { Minyak } \\
\text { Jelanta }\end{array}$ & $225 \mathrm{Liter}$ & 4.250 & 956.250 \\
\hline & & & 3.206 .250 \\
\hline
\end{tabular}

Sumber: Data diolah (2015)

Cara pengelolaan limbah makanan menjadi pupuk kompos menimbulkan biaya dalam proses pengelolaannya, biaya yang timbul dalam kegiatan tersebut bisa dilihat pada tabel 12.

Tabel 12 Estimasi beban pengelolaan limbah padat organik hotel berdasarkan metode daur ulang limbah padat organik sisa makanan menggunakan metode composting perbulan

\begin{tabular}{lr}
\hline \multicolumn{1}{c}{ Keterangan } & \multicolumn{1}{c}{$\begin{array}{c}\text { Estimasi Beban } \\
\text { Pengelolaan Per- } \\
\text { bulan (Rp) }\end{array}$} \\
\hline $\begin{array}{l}\text { Beban Penyusutan Drum } \\
\text { (Tong) }\end{array}$ & 21.333 \\
\hline $\begin{array}{l}\text { Beban Gaji Penanganan Lim- } \\
\text { bah Makanan }\end{array}$ & 1.300 .000 \\
\hline $\begin{array}{l}\text { Beban Penyusutan Mesin Pen- } \\
\text { cacah }\end{array}$ & 30.278 \\
\hline & 40.000 \\
\hline Beban Mikroorganisme & 1.391 .611 \\
\hline $\begin{array}{l}\text { Total } \\
\text { Sumber: Perusahaan pembuat }\end{array}$ & kompos, 2015 (data \\
\hline
\end{tabular}

Penyusunan Laporan Estimasi Laba Rugi Pengelolaan Limbah

Dari hasil penelitian menggunakan metode tukar menukar limbah untuk pengelolaan limbah padat dan metode daur ulang untuk pengelolaan limbah cair maka dapat disusun estimasi laporan laba rugi pengelolaan limbah. Laporan tersebut dapat dilihat pada tabel berikut.

Tabel 13 Laporan estimasi laba rugi pengelolaan limbah berdasarkan metode tukar -menukar pada limbah padat dan daur ulang pada limbah cair perbulan

\section{LAPORAN ESTIMASI LABA RUGI PENGELOLAAN LIMBAH}

\begin{tabular}{|c|c|}
\hline \multicolumn{2}{|l|}{ Pendapatan } \\
\hline $\begin{array}{l}\text { Pendapatan Dari Pengelolaan Limbah } \\
\text { Padat Anorganik (tabel 14) }\end{array}$ & Rp 19.889 .500 \\
\hline $\begin{array}{l}\text { Pendapatan Dari Pengelolaan Limbah } \\
\text { Padat Organik (tabel 15) }\end{array}$ & $\mathrm{Rp} \quad 3.206 .250$ \\
\hline Jumlah Pendapatan & Rp23.089.750 \\
\hline Beban-beban & \\
\hline $\begin{array}{l}\text { Beban Pengelolaan Limbah Padat } \\
\text { Anorganik }\end{array}$ & 100.000 \\
\hline $\begin{array}{l}\text { Beban Pengelolaan Limbah Padat Or- } \\
\text { ganik }\end{array}$ & Rp $\quad 1.350 .000$ \\
\hline Beban Pengelolaan Limbah Cair & Rp 1.890 .556 \\
\hline Jumlah Beban & Rp $\quad 3.340 .556$ \\
\hline Laba Pengelolaan Limbah & Rp $\quad 19.769 .194$ \\
\hline
\end{tabular}


Tabel 14 Rincian Estimasi Pendapatan dari Pengelolaan Limbah Berdasarkan Metode TukarMenukar pada Limbah Padat dan Daur Ulang pada Limbah Cair Perbulan

\begin{tabular}{lrrrr}
\hline \multicolumn{4}{c}{ RINCIAN ESTIMASI PENDAPATAN PENGELOLAAN LIMBAH } & \\
\hline & Kuant. & Sat. & Rp/sat & Rp \\
\hline Aki Bekas & 13 & $\mathrm{Kg}$ & 10.000 & 130.000 \\
Botol Makanan Kemasan & 180 & $\mathrm{Btl}$ & 1.250 & 225.000 \\
Botol Bir Bintang Pl & 600 & $\mathrm{Btl}$ & 1.750 & 1.050 .000 \\
Botol Heineken Pint 330ml & 840 & $\mathrm{Btl}$ & 1.250 & 1.050 .000 \\
Botol Minuman Keras & 175 & $\mathrm{Btl}$ & 15.000 & 2.625 .000 \\
Botol Teh & 600 & $\mathrm{Btl}$ & 550 & 330.000 \\
Comb & 4.560 & $\mathrm{Pcs}$ & 200 & 912.000 \\
Gelas Plastic & 6.840 & $\mathrm{Pcs}$ & 250 & 1.710 .000 \\
Jerigen & 50 & $\mathrm{Pcs}$ & 10.000 & 500.000 \\
Hand Soap Hk/Sabun Logo & 2.280 & $\mathrm{Pcs}$ & 420 & 957.600 \\
Kaleng Makanan Kemasan & 28 & $\mathrm{Kg}$ & 10.000 & 280.000 \\
Kaleng Minuman & 56 & $\mathrm{Kg}$ & 10.000 & 560.000 \\
Karton & 5 & $\mathrm{Kg}$ & 1.200 & 6.000 \\
Kertas & 35 & $\mathrm{Kg}$ & 1.700 & 59.500 \\
Plastik Botol Air Mineral & 170 & $\mathrm{Kg}$ & 4.000 & 680.000 \\
Razor/Shaving Kit & 760 & $\mathrm{Pcs}$ & 220 & 167.200 \\
Sendok Plastik & 4.560 & $\mathrm{Pcs}$ & 50 & 228.000 \\
Shampoo Hk & 2.280 & $\mathrm{Pcs}$ & 400 & 912.000 \\
Shower Gel & 2.280 & $\mathrm{Pcs}$ & 450 & 1.026 .000 \\
Slipper Logo & 4.560 & $\mathrm{Pcs}$ & 1.000 & 4.560 .000 \\
Tooth Brush & 4.560 & $\mathrm{Pcs}$ & 420 & 1.915 .200 \\
\hline Jumlah Pendapatan Pengelolaan Limbah Padat Anorganik & & & $\mathbf{1 9 . 8 8 3 . 5 0 0}$ \\
\hline Pendapatan dari Pengelolaan Limbah Padat Organik & & & & \\
Limbah Makanan & 1.500 & $\mathrm{Kg}$ & 1.500 & 2.250 \\
Minyak Jelanta & 225 & $\mathrm{Ltr}$ & $\mathbf{2 3 . 0 8 9 . 7 5 0}$ \\
\hline Jumlah Pendapatan Pengelolaan Limbah Padat Organik & & & $\mathbf{3 . 2 0 6 . 2 5 0}$ \\
\hline Total Pendapatan Pengelolaan Limbah Padat & & & \\
\hline
\end{tabular}

Sumber: Data diolah (2015)

Tabel 15 Rincian Estimasi Beban dari Pengelolaan Limbah Berdasarkan Metode Tukar-menukar pada Limbah Padat dan Daur Ulang pada Limbah Cair Perbulan

RINCIAN ESTIMASI BEBAN PENGELOLAAN LIMBAH (Rp)

\begin{tabular}{lr}
\hline Beban-Beban Pengelolaan Limbah Padat Anorganik: & \\
Beban Pengelolaan Limbah Baterai & 5.000 \\
Beban Pengelolaan Limbah Oli Bekas & 15.000 \\
Beban Penyimpanan Limbah Padat & 50.000 \\
\hline Jumlah Beban Pengelolaan Limbah Padat Anorganik & $\mathbf{1 0 0 . 0 0 0}$ \\
\hline Beban-Beban Pengelolaan Limbah Padat Organik & 1.300 .000 \\
Beban Gaji Penanganan Limbah & 50.000 \\
Beban Penyimpanan Limbah Makanan & $\mathbf{1 . 3 5 0 . 0 0 0}$ \\
\hline Jumlah Pengelolaan Limbah Padat Organik & 150.000 \\
\hline Beban Pengelolaan Limbah Cair & 35.000 \\
Beban Uji Laboraturium & 100.000 \\
Beban Cemikal & 50.000 \\
Beban Teskit & 1.527 .778 \\
Beban Kertas Lakmus & 27.778 \\
Beban Penyusutan Tabung Pengelolaan Limbah & $\mathbf{1 . 8 9 0 . 5 5 6}$ \\
Beban Perizinan Baku Mutu Limbah Cair & $\mathbf{3 . 3 4 0 . 5 5 6}$ \\
\hline Jumlah Beban Pengelolaan Limbah Cair &
\end{tabular}

Sumber: Data diolah (2015) 
Selanjutnya, dari hasil penelitian menggunakan metode tukar menukar limbah untuk pengelolaan limbah padat anorganik dan limbah padat organik berupa minyak jelantah serta menggunakan metode daur ulang limbah menjadi kompos untuk limbah padat organik berupa sisa makanan dan menggunakan metode Biotek untuk pengelolaan limbah cair maka dapat disusun estimasi laporan laba rugi pengelolaan tersebut. Laporan tersebut dapat dilihat sebagai berikut:

Tabel 16 Rincian Estimasi Pendapatan dari Pengelolaan Limbah Berdasarkan Metode TukarMenukar Untuk Limbah Padat Anorganik dan Daur Ulang untuk Limbah Padat Organik dan Limbah Cair Perbulan

\begin{tabular}{lr}
\hline \multicolumn{3}{c}{ LAPORAN ESTIMASI LABA RUGI PENGELOLAAN LIMBAH (Rp) } & \\
\hline Pendapatan & 19.883 .500 \\
\hline Pendapatan dari Pengelolaan Limbah Padat Anorganik (tabel 17) & 956.250 \\
\hline Pendapatan dari Pengelolaan Limbah Minyak Jelantah (tabel 18) & $\mathbf{2 0 . 8 3 9 . 7 5 0}$ \\
\hline Jumlah Pendapatan & 100.000 \\
\hline Beban & 1.391 .611 \\
\hline Beban Pengelolaan Limbah Padat Anorganik & 1.890 .556 \\
\hline Beban Pengelolaan Limbah Padat Organik & $\mathbf{3 . 3 8 2 . 1 6 7}$ \\
\hline Beban Pengelolaan Limbah Cair & $\mathbf{1 7 . 4 5 7 . 5 8 3}$ \\
\hline Jumlah Beban &
\end{tabular}

Sumber: Data diolah, 2015

Tabel 17 Rincian Estimasi Pendapatan Dari Pengelolaan Limbah Berdasarkan Metode TukarMenukar Untuk Limbah Padat Anorganik Dan Daur Ulang Untuk Limbah Padat Organik Dan Limbah Cair Perbulan

\begin{tabular}{|c|c|c|c|c|}
\hline \multicolumn{5}{|c|}{ RINCIAN ESTIMASI PENDAPATAN PENGELOLAAN LIMBAH } \\
\hline \multicolumn{5}{|c|}{ Pendapatan Dari Pengelolaan Limbah Padat Anorganik: } \\
\hline & & Sat & $@ \mathrm{Rp}$ & \\
\hline Aki Bekas & 13 & $\mathrm{Kg}$ & 10.000 & 130.000 \\
\hline Botol Makanan Kemasan & 180 & Btl & 1.250 & 225.000 \\
\hline Botol Bir Bintang PL & 600 & Btl & 1.750 & 1.050 .000 \\
\hline Botol Heineken Pint 330ml & 840 & Btl & 1.250 & 1.050 .000 \\
\hline Botol Minuman Keras & 175 & Btl & 15.000 & 2.625 .000 \\
\hline Botol Teh & 600 & Btl & 550 & 330.000 \\
\hline Comb & 4.560 & Pcs & 200 & 912.000 \\
\hline Gelas Plastik & 6.840 & Pcs & 250 & 1.710 .000 \\
\hline Gerigen & 50 & Pcs & 10.000 & 500.000 \\
\hline Hand Soap HK/Sabun Logo & 2.280 & Pcs & 420 & 957.600 \\
\hline Kaleng Bahan Makanan Kemasan & 28 & $\mathrm{Kg}$ & 10.000 & 280.000 \\
\hline Kaleng Minuman & 56 & $\mathrm{Kg}$ & 10.000 & 560.000 \\
\hline Karton & 5 & $\mathrm{Kg}$ & 1.200 & 6.000 \\
\hline Kertas & 35 & $\mathrm{Kg}$ & 1.700 & 59.500 \\
\hline Plastik Botol Air Mineral & 170 & $\mathrm{Kg}$ & 4.000 & 680.000 \\
\hline Razor/Shaving Kit & 760 & Pcs & 220 & 167.200 \\
\hline Sendok Plastik & 4.560 & Pcs & 50 & 228.000 \\
\hline Shampoo HK & 2.280 & Pcs & 400 & 912.000 \\
\hline Shower Gel & 2.280 & Pcs & 450 & 1.026 .000 \\
\hline Slipper Logo & 4.560 & Pcs & 1.000 & 4.560 .000 \\
\hline Tooth Brush & 4.560 & Pcs & 420 & 1.915 .200 \\
\hline \multicolumn{4}{|c|}{ Jumlah Pendapatan Pengelolaan Limbah Padat Anorganik } & 19.883.500 \\
\hline \multicolumn{5}{|c|}{ Pendapatan Dari Pengelolaan Limbah Padat Organik: } \\
\hline \multicolumn{4}{|c|}{ Total Pendapatan Pengelolaan Limbah Padat } & 20.839 .750 \\
\hline
\end{tabular}

Sumber: data diolah, 2015 
Tabel 18 Rincian Estimasi Beban dari Pengelolaan Limbah Berdasarkan Alternatif Metode Tukar -Menukar untuk Limbah Padat Anorganik dan Daur Ulang untuk Limbah Padat Organik dan Limbah Cair Perbulan

\begin{tabular}{lr}
\hline \multicolumn{2}{c}{ RINCIAN ESTIMASI BEBAN PENGELOLAAN LIMBAH (Rp) } \\
\hline Beban Pengelolaan Limbah Baterai & 5.000 \\
Beban Pengelolaan Limbah Oli Bekas & 15.000 \\
Beban Penyimpanan Limbah Padat & 50.000 \\
\hline Jumlah Beban Pengelolaan Limbah Padat Anorganik & $\mathbf{1 0 0 . 0 0 0}$ \\
\hline Beban Pengelolaan Limbah Padat Organik & 30.278 \\
Beban Penyusutan Mesin Pencacah & 21.333 \\
Beban Penyusutan Drum (Tong) & 1.300 .000 \\
Beban Gaji Penanganan Limbah & 40.000 \\
Beban Mikroorganisme & $\mathbf{1 . 3 9 1 . 6 1 1}$ \\
\hline Jumlah Beban Pengelolaan Limbah Padat Organik & 150.000 \\
\hline Beban Pengelolaan Limbah Cair & 35.000 \\
Beban Uji Laboraturium & 100.000 \\
Beban Cemikal & 50.000 \\
Beban Teskit & 1.527 .778 \\
Beban Kertas Lakmus & 27.778 \\
Beban Penyusutan Tabung Pengelolaan Limbah Cair & $\mathbf{1 . 8 9 0 . 5 5 6}$ \\
Beban Perizinan Baku Mutu Limbah Cair & $\mathbf{3 . 3 8 2 . 1 6 7}$ \\
\hline Jumlah Beban Pengelolaan Limbah Cair & \\
\hline Total Beban Pengelolaan Limbah & \\
\hline
\end{tabular}

Sumber: Data diolah, 2015

\section{Analisis Laporan Alternatif Pengelolaan Limbah Hotel}

Pengelolaan dengan alternatif waste material exchange atau tukar menukar limbah menimbulkan biaya yang relatif kecil. Beban yang timbul diestimasikan hanya berkisar $0,5 \%$ dari estimasi pendapatan yang bisa dihasilkan. Manfaat yang dapat diperoleh oleh pihak hotel sangat banyak jika menggunakan alternatif ini sehingga alternatif ini paling tepat diterapkan oleh pihak hotel. Pihak hotel mendapatkan manfaat berupa keuntungan material (tambahan pendapatan) dari hasil penjualan limbah.

Dengan menggunakan alternatif waste material exchange atau tukar menukar limbah menimbulkan biaya berupa beban gaji karyawan dan beban pengumpulan limbah. Beban yang timbul berkisar $42 \%$ dari estimasi pendapatan yang dihasilkan. Manfaat yang diperoleh pihak hotel jika menerapkan alternatif ini adalah berupa keuntungan material (tambahan pendapatan) dari hasil penjualan limbah organik. Tambahan pendapatan yang diterima mampu menutupi biaya yang timbul dari pengelolaan limbah.

Di sisi lain, pengelolaan limbah padat organik dapat menggunakan alternatif recycle atau mendaur ulang limbah menggunakan metode composting menimbulkan biaya yang relatif terjangkau bagi pihak hotel tetapi tidak menghasilkan tambahan bagi pihak hotel. Hasil olahan limbah yang berupa pupuk kompos dijadikan pihak hotel sebagai pupuk untuk menyuburkan tumbuhan-tumbuhan yang ada disekitar lingkungan hotel. Manfaat yang diterima pihak hotel berupa manfaat sosial yang didapatkan dari lingkungan sekitar hotel seperti masyarakat dan pemerintah karena hasil olahan dari limbah organik tersebut bisa dijadikan pihak hotel sebagai bentuk corporate social responsibility. Alternatif ini paling tepat diterapkan oleh pihak hotel.

Pengelolaan limbah cair hotel menggunakan alternatif recycle atau daur ulang menggunakan metode biotek menimbulkan biaya dalam proses pengelolaannya, tetapi mengelola limbah cair diharuskan oleh pemerintah 
sebelum dibuang ke saluran pembuangan.Manfaat yang diterima pihak hotel yaitu manfaat sosial berupa pengakuan dari pemerintah berupa peryataan bahwa pihak hotel telah ikut berpartisipasi untuk mencegah terjadinya pencemaran lingkungan serta menjaga keberlangsungan hidup masyarakat.

\section{KESIMPULAN}

Potensi pendapatan dan beban pengelolaan limbah atas limbah yang dihasilkan oleh pihak hotel menghasilkan pendapatan dan beban untuk setiap alternatif yang dipilih. Kinerja keuangan atas pengelolaan limbah berbeda berdasarkan alternatif yang diterapkan. Untuk pengelolaan menggunakan alternatif waste material exchange atau tukar menukar limbah, tambahan yang dihasilkan oleh pihak hotel berupa tambahan pendapatan dari hasil penjualan limbah yang dilakukan dapat menutupi beban pengelolaannya. Adapun limbah yang dikelola dengan menggunakan alternatif recycle atau mendaur ulang limbah, menghasilkan manfaat berupa keuntungan sosial yang diterima oleh pihak hotel, karena pihak hotel ikut berpartisipasi dalam program pelestarian lingkungan untuk mencegah terjadinya pencemaran lingkungan sehingga pihak hotel bertanggung jawab atas lingkungan dan masyarakat sekitar.

Aktivitas pengelolaan limbah hotel adalah aktivitas rutin sebagai dampak operasional hotel. Untuk menjamin sustainabiltas lingkungan sekaligus meningkatkan kinerja keuangan perusahaan, maka disarankan untuk menyusun alternatif pengelolaan limbah dan mengukur potensi laba yang bersumber dari pengelolaan limbah tersebut. Tentu saja perlu didukung dengan sistem akuntansi pengelolaan limbah.

\section{DAFTAR PUSTAKA}

Ahmad, Kamaruddin. 2011. Akuntansi Manajemen Dasar-dasar Konsep Biaya dan Pengambilan Keputusan. Jakarta: PT. Raja Grafindo Persada.

Anonim. Pengelolaan Limbah Industri Perhotelan.

Astari, Asih. 2015. (Online), (https:// www.academia.edu, diakses 05 agustus 2015).

Bagus, Denny. juni 2009. Jurnal Manajemen, Bahan Kuliah Manajemen. Klasifikasi/ penggolongan biaya., (Online), (http:// jurnal-sdm.blogspot.com/favicon.ico, diakses 03 agustus 2015).

Blocher, E. J. 2014. Manajemen Biaya Penekanan Strategi. Diahlibahasakan oleh David Wijaya. Jakarta: Salemba Empat.

Budiono, Aris. 29 Maret 2012. Manajemen Pengelolaan Limbah Padat, Cair, Gas dan B3., (Online), (http:// makalahariesbudiono.blogspot.com/ favicon.ico, diakses 06 Agustus 2015). Daryanto dan Agung Suprihatin. 2013. Pengantar Pendidikan Lingkungan Hidup. Yogyakarta: Gava Media.

Dunia, F.A. dan Wasilah Ahmad. 2012. Akuntansi Biaya. Jakarta: Salemba Empat.

Harahap, S. S. 2002. Teori Akuntansi Laporan Keuangan. Jakarta: Bumi Aksara.

Hansen, D., Mowen, M., \& Guan, L. (2007). Cost management: accounting and control. Cengage Learning.

Ikatan Akuntan Indonesia. 2012. Standar Akuntansi Keuangan. Jakarta: Salemba Empat.

Kautsar, R. S. 2013. Akuntansi Biaya Pendekatan Product Costing. Jakarta: Akedemia Permata.

Keputusan Menteri Lingkungan Hidup tentang Baku Mutu Limbah Cair Hotel No: KEP52/MENLH/10/95.

Keputusan Menteri Parriwisata, Pos, dan Telekomunikasi Republik Indonesia Nomor KM 37/P. 340/MPPT-86. Peraturan Usaha Dan Penggolongan Hotel. Jakarta.

Muhjad, M. H. 2015. Hukum Lingkungan Sebuah Pengantar untuk Konteks Indonesia. Yogyakarta: Genta Publishing.

Mukhlis, Amir. 25 Januari 2015. Kerusakan Lingkungan Akibat Industri., (Online), (http://amirmukhlis06.blogspot.com/ favicon.ico, diakses 03 agustus 2015).

Mulyadi. 2012. Akuntansi Biaya. Yogyakarta: UPP STIM YKPN.

Peraturan Pemerintah No. 32 Tahun 2009 Tentang Perlindungan Dan Pengelolaan Lingkungan Hidup, Jakarta. 
Rahmawati, S. E. 18 November 2011. Kerusakan Lingkungan Hidup Akibat Limbah Industri., (Online), (http://srieka.blogspot.com/favicon.ico, diakses 03 Agustus 2015).

Subardo Utami. 21 April 2013. Pengolahan dan penanganan limbah., (Online), (https://utamisubardo.wordpress.com/ xmlrpc.php, diakses 05 Agustus 2015).

Supriyono, R. A. 2011. Akuntansi Biaya: Pengumpulan Biaya dan Penentuan Harga Pokok. Yogyakarta: BPFE.

Suriana Lin. 10 April 2010. Perangkat Pembelajaran KTSP. Manajemen Pengelolahan Limbah dan Sampah., (Online), (https:// halil4.wordpress.com/xmlrpc.php, diakses 04 agustus 2015).

Suwardjono. 2014. Teori Akuntansi Perekayasaan Pelaporan Keuangan. Yogyakarta: BPFE.

Try Donny, 2010. Lingkungan. Upaya mengatasi pencemaran lingkungan., (Online), (http://lingkungan-donny.blogspot.com/ favicon.ico, diakses 06 agustus 2015).

Wahidin Samsul. 2014. Dimensi Hukum Perlindungan dan Pengelolaan Lingkungan Hidup. Yogyakarta: Pustaka Pelajar. 